\title{
PENINGKATAN MINAT BELAJAR SISWA MELALUI MEDIA AUDIO VISUAL DALAM PEMBELAJARAN FIQIH
}

Umi Muafiah

Institut Agama Islam Negeri Kudus

Ani Khoirun Nisa

Institut Agama Islam Negeri Kudus

M. Zaimus Syarofi

zasyarofi@gmail.com

Institut Agama Islam Negeri Kudus

Bunga Amanah F.

Institut Agama Islam Negeri Kudus

\section{Ulya Fawaida}

lfawaida@yahoo.com

Institut Agama Islam Negeri Kudus

DOI: $10.21580 /$ wa.v6i2.5403

\begin{abstract}
The development of the times makes technology development also increasing. In the world of learning, as an example of the development of technology in the modern era, in order to attract students' interest in learning, various efforts have been made by the school, one of which is by using audio visuals in learning. In fact, this method is very effective to use in addition to attracting audio-visual students as well as many benefits. With a learning system that uses this media, you can use the method used to increase students 'interest in learning in schools in the example of applying the media used to attract students' interest in learning Islamic Civilization History.
\end{abstract}

Keywords: Learning Interests, Audio Visual Media, Fiqh Learning 


\begin{abstract}
Abstrak
Berkembangnya zaman membuat pengembangan teknologi juga semakin meningkat. Dalam dunia pembelajaran sebagai contoh adanya pengembangan teknologi di era modern, demi menarik minat belajar siswa berbagai upaya dilakukan oleh pihak sekolah salah satunya dengan menggunkan Audio visual daalam pembelajaran. Nyatanya metode ini sangat efektif digunakan selain untuk menarik minta siswa Audio visual juga banyak manfaatnya. Dengan sistem pembelajaran yang memakai media ini dapat menggunakan metode yang dipakai untuk meningkatkan minat belajar siswa di sekolah pada contoh penerapan media yang dipakai untuk menarik minat siswa dalam pembelajaran Fiqih.
\end{abstract}

Kata Kunci: Minat Belajar, Media Audio Visual, Pembelajaran Fiqih

\title{
A. Pendahuluan
}

Berkurangnya minat belajar siswa dikarenakan oleh beberapa faktor salah satunya adanya metode yang disampaikan oleh para pendidik terkesan membosankan dan kuno. Membuat banyak siswa malas dengan penyampaian materi yang sudah seperti narasi itu. Demi mensiasati adaanya pengurangan minat belajar siswa untuk itu banyak sekali inovasi yang dilakukan oleh lembaga pendidikan seperti pada penerapan sistem pembelajaran yang menggunakan Audio Visual.

Dengan mengubah sistem pembelajaran pada penggunaan media audio visual ini terbukti berhasil dan menimbulkan respon yang positif dan dampak yang diberikan kepada siswa juga baik, di terimanaya penerapan sistem ini di dunia pendidikan membuat sistem ini tidak hanya untuk sangkut paut dalam satu pelajaran tapi semua pelajaran bisa menggunakan media tersebut alangkah baiknya cara sistem yang diterapkan pada sekolah agar untuk bisa digunakan dalam semua pelajaran, dengan itu para siswa bisa mencerna pelajaran media dengan baik dan tepat.

Adanya penerapan tersebut dalam kegiatan penyampaian materi tentang agama seperti fiqih kepada peserta didik bisa mengambil contoh dari media apa saja yang digunakan seperti bentuk film dibuat sebuah animasi agar minat belajar siswa menjadi menambah untuk ingin rasa taunya sangat ada. Untuk itu media Audio Visual ini sangat dibutuhkan demi menarik minta belajar siswa dan untuk membantu para pendidik dalam menyampaikan materi lebih mudah

\section{B. Pembahasan}

\section{Peningkatan Minat Belajar Siswa}

a. Minat

Salah satu point untuk meningkatkan belajar siswa adalah dengan minat itu sendiri, minat itu sendiri di dapat dari diri siswa. Seperti yang di jelaskan dalam kamus lengkap 
Bahasa Indonesia, Minat berarti Keinginan, kesukaan, kehendak. ${ }^{1}$ Tanpa minat siswa akan sangat malas untuk balajar. Diketahui juga bahwa menurunnya minat siswa dalam belajar di sekolah adalah dikarenakan metode pembelajaran yang dipakai oleh para pendidik sangat membosankan sehingga metode tersebut seperti penyampaian narasi membuat siswa menurunnya minat belajar. Di sebutkan juga oleh Hilgard (dalam Tohirin, 2003) menjelaskan: Interest is persiting tendency to payattention to and enjoysomeectivity or conten. Demikian itu, minat merupakan suatu hal yang cenderung tetap untuk memperhatikan beberapa kegiatan. ${ }^{2}$

Demi membangun ketertarikan untuk belajar para peserta didik perlu adanya sebuah motivasi dan inovasi pembaharuan yang dapat meningkatkan minat belajar siswa agar lebih semangat dalam menerima materi yang di sampaikan oleh para pendidik karena minat belajar juga dapat mempengaruhi prestasi siswa itu sendiri. Jika bukan para pendidik yang mensiasati dan memperbaharui metode pembelajaran akan ada siapa lagi. Dalam kutipan buku menyebutkan bahwa "Minat dalam proses belajar mengajar merupakan salah satu faktor yang besar pengaruhnya terhadap prestasi belajar. Siswa yang minta belajarnya tinggi akan memperoleh prestasi belajar baik. Pentingnya motivasi belajar terbentuk antara lain agar terjadi perubahan belajar ke arah lebih positif. Pandangan ini sesuai dengan pendapat Hawley yang dikemukakan Wardiana (2004: 149) bahwa siswa yang memiliki minat belajar tinggi akan melakukan kegiatan lebih banyak dan lebih cepat, dibandingkan dengan siswa yang kurang termotivasi dalam belajar. Prestasi yang diraih akan lebih baik apabila mempunyai minat belajar tinggi “. 3

\section{b. Meningkatkan Mutu Pembelajaran}

Mutu dari materi adalah proses komunikasi antara peserta didik dengan sumber belajar. Dalam konteks ini mutu tersebut mengacu pada proses dan dampak yang di hasilkan saat proses itu berlangsung. Untuk membangun itu semua faktor terpentingnya kualitas pendidikan adalah kompetensi pendidik dalam merumuskan dan melakukan pelaksanaan kegiatan belajar adalah pada pendidik itu sendiri yang wajib memiliki penguasaan skill untuk menggambarkan, melakukan pengembangan, dan menggunakan pemanfaatan media pada proses peningkatan minat, penelitian, dan memberi dorongan. Dengan meningkatkan dorongan belajar dan minat kepada para siswanya, serta agar dapat menerima dengan baik materi yang telah disampaikan. ${ }^{4}$

\section{c. Strategi Meningkatkan Mutu Pendidikan}

Demi meningkatkan upaya mutu pendidikan, pemerintahan menerapkan Peraturan Pemerintah No. 19 tahun 2005 tentang "Standar Nasional Pendidikan”. Dalam fungsinya sebagai pokok perencanaan, pelaksanaan dan pengawasan pendidikan untuk menciptakan pendidikan nasional dengan mutu tinggi. Tujuan penetapan tersebut untuk menunjang

\footnotetext{
${ }^{1}$ Novianto, Kamus Besar Bahasa Indonesia, hal. 357

${ }^{2}$ Tohirin, Psikologi Pembelajaran Pendidikan Agama Islam, Pekanbaru, 2003, hal. 102

${ }^{3}$ Rusmiati, Pengaruh Minat Belajar Terhadap Prestasi Belajar Bidang Studi Ekonomi Siswa MA AL FATTAH Sumbermulyo, Vol. 1, No. 1, Februari 2017, Hal.23

${ }^{4}$ Muhammad Yaumi, Media dan Teknologi Pembelajaran, Prenamedia Group, Jakarta, 2018, Hal. 13
} 
pendidikan nasional dalam mencerdaskan kehidupan bangsa dengan watak bangsa yang bermartabat. Seperti yang di jelaskan dalam pembukaan UUD 1945 pada alenia 4 dengan isi tujuan dari negara salah satunya dengan mencetak generasi muda bangsa, untuk itu demi meningkatkan minat belajar siswa, lembaga pendidikan harus memberi inovasi dalam pembelajaran nantinya.

Edward Sallis mengatakan beberapa hal yang dijadikan dasar nilai pendidikan, yaitu: dengan pengadaan fasilitas yang memadai, pendidik yang mempunyai kompetensi bagus, nilai karakter karyawan yang tinggi, nilai ujian yang baik, mendapat dorongan motivasi dari orang tua, dan dukungan masyarakat sekitar, sumber yang mencukupi, aplikasi teknologi baru, kepemimpinan yang demokrasi, serta adanya kurikulum yang sesuai. Untuk itu peningkatan nilai pada dunia pendidikan karena bagian dari kebutuhan wajib disampaikan dan dirasakan oleh peserta didik, pendidik, orang tua, masyarakat. ${ }^{5}$

\section{Pembelajaran Menggunakan Audio Visual}

\section{a. Definisi Media Belajar}

Media belajar adalah sebuah alat bantu dimana untuk mempermudah baik itu siswa maupun pendidik dalam melangsungkan kegiatan belajar dalam kelas bisa berupa media cetak, audio visual, Proyektor dan sebagainya. Menurut salah satu ahli yang menyebutkan media sebagai saran fisik dalam penyampaian materi pada buku, film, video dan lain-lain di kemukakan oleh Briggs (1997). Dilanjut dengan pendapat beberapa ahli lainnya yang menurut National Education Association (1969) mengungkapan bahwa media sebagai fasilitas interaksi bentuk cetakan, termasuk teknologi dan penempatan media oleh Briggs (1997).

Sebab itu, proses pembelajaran dapat diartikan sebagai proses komunikasi dan berlangsungnya proses tersebut, sehingga mempunyai posisi penting sebagai salah satu kompenen dalam aspek pembelajaran. Tidak diterapkan media, membuat komunikasi tidak akan terlaksanakan dengan baik proses kegiatan yang berlangsung, juga dapat dijadikan bagian dari proses berlangsungnya proses belajar mengajar secara efisien. Media pembelajaran adalah komponen integral dari sistem pembelajaran.

\section{b. Peran Media Sebagai Alat Komunikasi}

Peran media dalam dunia pembelajaran sangatlah banyak. Selain sebagai alat bantu para pendidik, media juga bisa difungsikan sebagai alat bantu komunikasi, dimana kegiatan belajar tergantung pada pendidik. Akan tetapi media tidak banyak digunakan oleh pendidik. Sedangkan media sangat membantu berjalannya proser belajar mengajar. Namun terdapat pendidik yang tidak mau menggunakan media dalam proses pembelajaran yang dilangsungkannya. Hal ini memberi isyarat bahwa kurangnya langkah pemberdaya dan perubahan inovasi dalam dunia pendidikan seperti media pada proses pembelajaran. Malah berbanding terbalik dengan hal tersebut membuat sistem kegiatan belajar tidak perlu menunggu kehadiran pendidik.

${ }^{5}$ Pendi Susanto, Produktivitas Sekolah, Alfabeta, Bandung, 2016, Hal.60 
Dalam suasana proses belajar dengan basis pendidik, yang memberikan arahan kepada peserta didik. Dalam menggunakan media media belajar guna memberi dorongan semangat langsung pada para pendidik. Percaya bahwa media pembelajaran yang telah dirancang sedemikian rupa itu dapat memadai dan juga bisa di gunakan untuk meningkatkan serta meningkatkan hasil kegiatan belajar siswa di sekolah serta dapat memberi dukungan terhadap sistem pembelajaran yang berbasis guru untuk meningkatkan nilai efektifitas media pembelajaran yang juga tergantung pada guru itu sendiri. ${ }^{6}$

\section{c. Fungi Media Pembelajaran}

Fungsi media pembelajaran sangat lah luas begitu juga terdapat beberapa pendapat mengenai fungsi media pembelajaran itu sendiri. Menyinggung tentang peranan media dalam kegiatan pembelajaran, media pembelajaran itu dianggap sebagai bagian yang sangat untuk menentukan efektivitas dan efisiensi pencapaian tujuan. McKown menjelaskan "Audio Visual Aids To Intruction" terdapat empat fungsi media. Yaitu: Pertama, mengubah problem pendidikan resmi, maksudnya dengan adanya media yang tadinya kurang jelas menjadi jelas, pembelajaran yang hanya berisi teori menjadi penggunaan praktis. Kedua, meningkatkan motivasi belajar. Ketiga, memberikan penjelasan, supaya ilmu pengetahuan dan wawasan peserta didik dapat dimengeti. Ke empat yaitu memberikan rangsangan pada proses belajar. Keingintahuan yang tinggi perlu adanya rangsangan untuk muncul rasa keingintahuan melalui penyediaan media.

Rowtree mengemukakan fungsi media, yaitu: 1) membangun dorongan motivasi belajar, 2) mengulas yang telah dipelajari, 3) menyediakan rangsangan belajar, 4) menghidupkan respon peserta didik, 5) memberi umpan balik, dan 6) menggalakan latihan serasi. ${ }^{7}$ Sudah sangat jelas bahwa fungsi media pembelajaran sangatlah banyak dan tentu sangat bermanfaat bagi para pendidik dan juga siswa.

\section{d. Pemanfaatan Program Media}

Media yang digunakan dalam pembelajaran tentu pasti sudah dirancang sedemikian rupa untuk memudahkan para pendidik dalam porses mengajar. Media ini di program dengan berbagai macam cara dan sarana sesuai konsep runtut melalui langkah pengembangan mengikutsertakan tenaga pendidik yang berkompeten, dengan menggunakan peralatan. Hal tersebut, bisa diinginkan bahwa program dengan hasil itu dijadikan sebagai media yang efisien. Namun tidak semua lembaga pendidikan menggunakan program media dengan sanagat baik dan itu akan menghilangkan fungsi program media yang sesungguhnya. Maka dari itu, perlu dibuat dengan sebaik mungkin tidak hanya melalui pembuatan media itu, pemanfaatan tersebut perlu diatur dan dikonsep dengan baik. Demikianlah media itu merupakan alat bantu belajar. Agar menjadi lebih

${ }^{6}$ M. Miftah, Fungsi, dan Peran Media Pembelajaran Sebagai Upaya Peningkatan Kemampuan Belajar Siswa, Jurnal KWANGSAN Vol. 1, No. 2, Desember 2013, Hal. 101

${ }^{7}$ M. Miftah, Fungsi dan Peran Media Pembelajaraan Sebagai Upaya Peningkatan KemampuanBelajar Siswa, Jurnal KWANGSAN, Vol. 1, No. 2, Desember 2013, Hal. 100 
efektif, pemanfaatan media itu perlu dikonsepkan dengan baik dan runtut. ${ }^{8}$ Dan diharapakan alat bantu itu bisa memantau para tenaga kependidikan untuk lebih memajukan dan memotivasi para siswa dalam minat belajar.

\section{e. Media Pendidikan}

Media pendidikan istilah itu sudah tidak asing lagi rasanya untuk di dengar khalayak umum terlebih lagi di lingkungan pendidikan namun, istilah pengaplikasian untuk menggambarkan media pembelajaran. Namun masih terdapat yang memakai istilah komunikasi peragaan. Sedangkan pada kepustakaan luar untuk sementara ahli yang memakai istilah audio visual aids untuk yang sama, beberapa pengemuka memakai istilah pembelajaran materi atau penginstruksian pembelajaran.

Maka dari itu beragamnya penjelasan arti, yang mana memiliki tekanan, sehingga lebih bagus apabila menggunakan salah satu diantaranya "media pendidikan". Ciri-ciri umum dari alat bantu pendidikan yaitu:

1) Media identik pada artian sebagai keperagaan, dari kata "raga" yaitu benda yang dapat dipegang, dilihat, didengar dan bisa di amati oleh indera kita.

2) Media difungsikan dalam interaksi pembelajaran, pendidik dengan peserta didik.

3) Media juga di gunakan seperti semacam alat bantu bagi pendidik untuk pembelajaran di dalam ruangan mapun diluar ruangan.

4) Media diartikan sebagai penyambung dalam proses kegiatan belajar demi mempermudah proses pendidikan itu berlangsung.

5) Media terdapat aspek; sebagai alat bantu dan sebagai teknik, yang erat kaitannya dengan metode pengajaran.?

\section{f. Penggunaan Media}

Media visual menjadikan satu pada penggunaan audio memerlukan proses tambahan dalam pengelolaannya. Salah satu pemrosesan penting sangat perlu pada media audio visual adalah penulisan materi belajar dengan melakukan persiapan, tantangan dan penelitian.

Materi sebagai bahan yang perlu dipilah lebih dulu tentang isi pelajaran kemudian kembangkan pada penyampaian. Hal ini sebagai pembantu oleh kelompok pengelolaan dalam memikirkan bagaimana video memvisualisasi materi pelajaran tersebut. Pada proses belajar yang pertama media harus memperlihatkan sesuatu menarik perhatian pada peserta didik. Hal ini sebagai langkah yang masuk akal pada keseluruhan program yang berkesinambungan dan memberikan kesimpulan rangkuman. Kontinuitas proses perlu adanya pengembangan melalui penggunaan cerita permasalahan kemudian dilakukan pemecahannya.

${ }^{8}$ Arief S. Sadiman, dkk, Media Pendidikan, Pengertian, Pengembangan dan Pemanfaatannya, PT Raja Grafindo Persada, Jakarta, 2012, Hal. 189

${ }^{9}$ Usman, M. Basyiruddin-Asnawir, Media Pembelajaran, Ciputat Press, Jakarta, 2002, Hal. 11-12 


\section{g. Pengembangan Media}

Alat bantu audio visual adalah alat kegiatan belajar efektif dan efisien. Dengan membeli peralatan seperti tape recorder, tidak memerlukan tambahan biaya, dikarenakan bisa dihapus setelah menggunakan alat tersebut. Disamping itu juga terdapat materi suara untuk disesuaikan pada kemampuan peserta didik. ${ }^{10}$

Prinsip-prinsip pengembangan media untuk proses belajar umumnya dengan mengembangkan multimedia belajar untuk memperhatikan prinsip VISUALS, yang dapat digambarkan sebagai singkatan dari kata-kata: Visible, Interesting, Simple, Useful, Accurate dan Legitimate.

Kentut (2009), menjelaskan pengembangan alat bantu perlu dikerjakan sesuai prinsip pengembangan media kegiatan belajar. Prinsip perlu adanya pertimbangan saat akan melakakukan pengembangan pada alat bantu proses belajar.

Pertama, dikembangkan sesuai langkah pengembangan intruksional, pada dasarnya media presentasi di buku ini untuk keperluan pembelajaran. Maka perlunya penerapan prinsip seperti ini, sehingga bahan presentasi hasilnya kurang efektif dalam mencapai tujuan pembelajaran. Atau hamper sama dengan bahan presentasi informasi pada umumnya.

Kedua, perlu diingat alat bantu pembelajaran mempunyai fungsi sebagai bahan pendukung belajar. Media pembelajaran kurang tepat jika digunakan sebagai evaluasi pengayaan. Berbeda sekali program multimedia interaktif. Demikian ini, pesan yang diperlihatkan dibuat secara garis besar.

Ketiga, pengembangan alat bantu belajar mempertimbangkan secara kontinu pada kemampuan dan karakteristik yang dimiliki. Komponen yang perlu diperdayakan pada pembuatan media pembelajaran ini antara lain memiliki kemampuan untuk menampilkan teks, gambar, animasi, dan unsur audio-visual. Sedapat mungkin unsur-unsur tersebut dapat dimanfaatkan secara maksimal dalm pembuatan media pembelajaran yang akan dibuat.

Keempat, prinsip kebenaran materi dan kemenarikan sajian. Materi yang disajikan harus benar substansinya dan disajikan secara menarik pula. ${ }^{11}$

\section{h. Kelebihan dan Kelemahan Audio}

Kelebihan audio di dalam multimedia adalah sebagai media untuk memberikan dorongan; untuk menyampaikan materi tertentu; membantu peserta didik fokus pada materi yang dipelajari karena cukup mendengarkan dan dituntut konsentrasi. Berbeda dengan peserta didik yang melihat teks pada layar komputer harus melakukan berbagai kegiatan membaca teks, mencari kata kunci dari materi, dan menggerakkan tangan. Kelemahan audio di dalam multimedia adalah membutuhkan ruang penyimpanan besar di

${ }^{10}$ Ibid148-149

${ }^{11}$ M. Miftah, Fungsi dan Peran Media Pembelajaraan Sebagai Upaya Peningkatan KemampuanBelajar Siswa, Jurnal KWANGSAN, Vol. 1, No. 2, Desember 2013, Hal. 103-104 
dalam komputer: memerlukan perangkat lunak dan perangkat keras yang spesifik agar suara dapat disampaikan melalui komputer ${ }^{12}$.

\section{i. Pembelajaran Fiqih}

\section{1) Pengertian Fiqih}

Kata fiqih dan tafaquh, keduanya berarti "pemahaman yang dalam". Dalam terminologi Al-Qur'an dan As-Sunnah, fiqh adalah pengetahuan luas dan menyeluruh berkaitan perintah-perintah dan keadaan islam dan kurangnya relevansi khusus pada ilmu tertentu. Akan tetapi, dalam terminologi ulama, istilah fiqih secara dikhususkan dan diterapkan pada pemahaman yang mendalam atas hukum-hukum islam. ${ }^{13}$

\section{2) Kemampuan Peserta Didik Dalam Mempraktikkan Shalat}

Pada dasarnya video pembelajaran dapat dianggap sebagai salah satu yang menjadi pilihan para pendidik untuk menyampaikan materi mengatasi berbagai permasalahan yang ada dan untuk mengajar kepada peserta didik agar para peserta didik bisa menerima dengan jelas apa yang ingin disampaikan oleh para pendidik lewat teori yang mereka jelaskan terutama dalam hal mempraktikan shalat, maka guru harus menggunakan video pembelajaran dengan adanya gambar yang disertai dengan suara dapat meningkatkan kemampuan peserta didik dalam mempraktikan shalat yang ditampilkan oleh guru melaui video. Maka dari itu dengan menggunakan video pembelajaran dapat mengefektifkan serta meningkatkan kemampuan peserta didik dalam mempraktikan shalat. Dengan demikian mempraktikkan shalat dengan menggunakan video bagi peserta didik lebih menarik perhatian serta memudahkan mereka dalam mencermati materi yang disajikan lewat video pembelajaran.

Guru bisa menjelaskan pelajaran seperti materi shalat dan lain sebagainya dengan menerapkan media pembelajaran audio visual yang bisa berupa laptop, speaker, LCD dll. Untuk membantu peserta didik dalam mencermati dan memahami dan mengetahui gerakan-gerakan shalat agar lebih jelas dibanding dengan guru yang hanya mengungkapkan teorinya saja. Selain efektifias yang di dapat dari menerapaknnya metode pembelajaran Audio Visual sangat berdampak positif untuk meningkatkan kemampuan dan pemahaman anak akan praktik shalat, karena dengan video pembelajaran ini mamou untuk mendorong dan membangkitkan minat peserta didik dalam mengikuti proses kegiatan belajar. ${ }^{14}$

\section{j. Implementasi Minat Siswa Dalam Pembelajaran Menggunakan Audio Visual}

Untuk mengimplementasi dalam pemilihan media berdasarkan langkah-langkah seperti yang diketahui tadi merupakan hal penting yang seharusnya dilakukan oleh

\footnotetext{
${ }^{12}$ Muni, MIT,Pembelajaran Digital, ALFABETA cv, Bandung, 2017, hal. 151

${ }^{13}$ Abdul Hamid, Bani Ahmad Saebani, Fiqh Ibadah, CV PUSTAKA SETIA, Bandung, 2015, hal 11

${ }^{14}$ Devikasari A.H. Datau, Muh Arif, Efektivitas Pengguaan Video Pembelajaran Dalam Meningkatkan Kemampuan Mempraktikkan Shalat bagi Peserta Didik, Jurnal Irfani volume 14 no 2 desember, 2019, hal 4-5
} 
pendidik. Merajuk pada realitas empirik nya itu sangat mengejutkan karena dikatakan masih banyak pendidik dalam proses mengajarnya malah mengandalkan dirinya sendiri dan beranggapan bahwa dirinya tersebut sebagai satu-satunya sumber media dalam mengajar, selain itu mengandalkan papan tulis black board juga masih banyak digunakan sebagai media pembelajaran yang terkesan bahwa itu juga mrupakan satu-satunya media yang ada dalam proses pembelajaran. Padahal teknologi sudah semakin berkembang dan harusnya juga lembaga pendidikan itu mengarahkan dalam pembaharuan dalam dunia pendidikan memberi inovasi baru yang fresh untuk proses pendidikan itu berlangsung. Akan tetapi hal sebut juga tidak akan terjadi apabila pendidik itu memiliki kemampuan dalam merubah tatanan pembelajaran yang biasa di gunakan dari zaman ke zaman dengan merubahnya ke ara pendidikan yang menggunakan sistem pembelajaran yang brau dan modern. Jug mengenai langkah-langkah pemilihan media berdasarkan kriteria atau ketentuan yang telah disebutkan, dengan adanya perhatian pimpinan terkait hal tersebut dengan pentingnya peningkatan kualitas dan mutu pendidikan. Dengan memperhatikan mutu belajar yang diciptakan diharapkan dapat menciptakan sebuah inovasi dan rangkaian sistem pembelajaran lainnya yang dapat menungjang kualitas dalam dunia pendidikan lebih maju. Lebih lanjut jika pendidik tidak menggunakan langkah konsep dan pemilihan media menunjukkan indikasi kurangnya inovasi dan pengembangan media belajar yang digunakan. Sehingga pendidik fokus pada satu media saja. ${ }^{15}$

Media selalu di fungsikan sebagai salah satu alat berinteraksi dalam penyampaian informasi sangat berguna apabila diaplikasikan ke dalam proses pembelajaran,. Heinich dkk (Arsyad, 2005:4) mengatakan media pembelajaran sebagai penyalur yang mengantarkan informasi kepada sumber dan penerima. Jadi televisi, film, foto, rekaman audio dan sejenisnya adalah media komunikasi. Jika media itu memberikan pesan-pesan atau informasi bertujuan intruksional mengandung maksud pengajaran, maka disebut media pembelajaran. ${ }^{16}$

Penggunaan media film dalam pembelajaran sangat bermanfaat dan juga dapat merangsang otak yang nantinya akan mampu membantu mengubah pola pikir siswa itu sendiri karena dengan media tersebut dapat merangsang penglihatan, pendengaran, dan motorik siswa sehingga dapat meningkatan kegiatan belajar dan hasil belajar siswa. Media film bersifat tidak terikat dengan sisitem pembelajaran yang berlangsung sehingga siswa dapat belajar kapan saja sesuai yang di inginkan, media film ini juga dikenal mampu untuk meningkatkan kreatifitas siswa. Dari semua itu yang terpenting adalah peranan media film itu sendiri yaitu diantaranya mampu merekam kejadian masa lalu untuk di dokumentasikan serta dapat dipakai pembelajaran masa yang akan datang ${ }^{17}$. Media film juga dapat di aplikasian kesemua mata pejaran yang berbasis umum maupun agama salaah satunya adalah dengan menerapkan media pembelajaran kedalam maa pelajaran Fiqih, dengn menggunakan media ini sangat cocok digunakan dalam hal penyampaian materi

\footnotetext{
${ }^{15}$ Nunu Mahnun, Media Pembelajaran (Kajian terhadap Langkah-langkah Pemilihan Media dan Implementasinya dalam Pembelajaran), Jurnal Pemikiran Islam; Vol. 37, No. 1, Januari-Juni, 2012, Hal. 31 ${ }^{16} \mathrm{Ibid}^{169}$

17 Ulya Fawaida, Pengembangan Perangkat Pembelajaran Subkonsep Invertebrata dengan Media Film SMA, Jurnal THABIEA, Vol.02, No.01, 2019, Hal.21
} 
oleh para pendidiki itu sendiri, dengan mengubah sistem pembelajaran yang awalnya dilakukan hanya dengan metode cermah yang sudah pasti siswa akan merasa jenuh mendengarkan penjelasan dari guru, untuk mensiasati itu semua media film ini di masukkan untuk mengubah susasan dan pola pikir siswa, dengan adanya media film proses pembelajaran akan kembali hidup ketika pada materi yang akan diajarkan ditampilkan lewat film untuk ditonton peserta didik. Mereka dapat menerima materi dengan baik serta mendapatkan hiburan tersendiri karena adanya pembelajaran dengan media film.

\section{Kesimpulan}

Berdasarkan hasil pembahasan, melihat penjelasan materi disimpulkan bahwa implementasi dari kegiatan belajar fiqih pada media audio visual menjadikan kegiatan tersebut semakin aktif dan efektif selama berkembangnya zaman, hal ini kita sebagai pendidik dituntut untuk memberikan respon pada hasil tersebut. Dengan diwujudkannya pada penggunaan teknologi media sebagai sarana penunjung pembelajaran. Terdapat peningkatan hasil belajar sebelum diterapkan media audio visual dengan setelah diterapkan media audio visual.

Berdasarkan hasil belajar fiqih peserta didik sebelum diterapkannya proses belajar melalui media audio visual meningkat. Peningkatan hasil belajar siswa dapat dilihat dari perhitungan dan diperoleh kesimpulan bahwa rata-rata hasil belajar peserta didik sangat baik. Hasil belajar siswa pada mata pelajaran fiqih dengan melalui media tersebut mengalami peningkatan signifikan. Sehingga dapat disimpulkan bahwa pembelajaran melalui media audio visual dapat meningkatkan hasil belajar siswa. Beberapa saran yang konstruksif dapat diberikan demi kemajuan kegiatan belajar pendidikan agama islam, yaitu minatnya siswa PAI karena metode konvensional digunakan oleh pendidik. Pendidik diharuskan memiliki variasi dalam proses kegiatan belajar agar tidak mononton.

\section{Daftar Pustaka}

Datau, Devikasari A.H- Muh Arif. Efektivitas Pengguaan Video Pembelajaran Dalam Meningkatkan Kemampuan Mempraktikkan Shalat bagi Peserta Didik.JurnalIrfani. Vol.14No.2Desember. 2019.

Fawaida,Ulya. Pengembangan Perangkat Pembelajaran Subkonsep Invertebrata dengan Media Film SMA. Jurnal THABIEA. Vol.02. No.01. 2019.

Hamid.Abdul. Bani Ahmad Saebani.2015. Figh Ibadah. Bandung.CVPUSTAKA SETIA.

Hamzah, B. Uno-NinaLamatenggo. 2010. Teknologi Komunikasi dan Informasi Pembelajaran.Jakarta. PT Bumi Aksara.

Mahnun, Nunu. Media Pembelajaran (Kajian terhadap langkah-langkah pemilihan media dan implementasinya dalam pembelajaran) Jurnal Pemikiran Islam. Vol. 37. No.1. 2012.

Miftah,M. Fungsi dan Peran Media Pembelajaraan Sebagai Upaya Peningkatan KemampuanBelajar Siswa. Jurnal KWANGSAN.Vol.1.No.2. Desember2013.

Muni-MIT. 2017.PembelajaranDigital. Bandung. ALFABETAcv. 
Novianto. Kamus Besar Bahasa Indonesia.

Rusman, Deni Kurniawan. Cepi Riyana. 2013. Pembelajaran Berbasis Teknologi Informasi dan Komunikasi. Jakarta. PT RAJA GRAFINDO PERSADA.

Rusmiati. Pengaruh Minat Belajar Terhadap Prestasi Belajar Bidang Studi Ekonomi Siswa MA AL FATTAH Sumbermulyo. Vol. 1. No. 1. Februari 2017.

S, Arief-Sadiman, dkk. 2012.Media Pendidikan. Pengertian. Pengembangan dan Pemanfaatannya. Jakarta. PT Raja Grafindo Persada.

Susanto, Pendi. 2016. Produktivitas Sekolah. Bandung. ALFABETA.

Tohirin. 2003.Psikologi Pembelajaran Pendidikan Agama Islam. Pekanbaru.

Usman, M. Basyiruddin-Asnawir. 2002. Media Pembelajaran. Jakarta. Ciputat Press.

Yaumi, Muhammad. 2018. Media dan Teknologi Pembelajaran. Jakarta. Prenamedia Group. 